\title{
Effects of Neem, Tulsi and Ginger Extract as a Growth Promoter in Broilers Production
}

\author{
S. S. Biswas ${ }^{1}$, M. Mostafa ${ }^{1}$ and S. S. Saha ${ }^{2 *}$ \\ ${ }^{1}$ Department of Pharmacology, Bangladesh Agricultural University, \\ Mymensingh, Bangladesh \\ ${ }^{2}$ Department of Pathology and Parasitology, Patuakhali Science and Technology University, \\ Babugonj, Barishal, Bangladesh \\ *Corresponding author
}

\section{A B S T R A C T}

This study was conducted to determine the efficacy of leaves of Neem (N) and Tulsi (T), and Ginger (G) i.e. NTG extract as a growth promoter in broilers. A total of 20 day old broiler chicks were purchased from Kazi Farms Limited, and after seven days of

\begin{tabular}{|l|}
\hline Key w or d s \\
Neem, Tulsi, \\
Ginger, Growth \\
Promoter, Broiler \\
\hline Article Info \\
\hline $\begin{array}{l}\text { Accepted: } \\
\text { 05 February } 2020 \\
\text { Available Online: } \\
\text { 10 March 2020 }\end{array}$ \\
\hline \hline
\end{tabular}
acclimatization it was divided into two equal groups, i.e., group A and group B. No vaccination schedule was practiced and no antibiotics were added in the ration of these broilers. Group A served as control group and was not supplemented with NTG extract while group B was supplemented with NTG extract @ 1ml/litre in drinking water. Weekly observations were recorded for live body weight gain upto $6^{\text {th }}$ weeks and blood parameter was checked at $21^{\text {st }}$ and $42^{\text {nd }}$ days age of broiler to find out hematological changes between control (Group-A) and treatment (group-B). The FCR value in group A was 1.87 and in group B was 1.82; the result indicated that NTG extract played important role in broiler production. Mortality rate in group-B was nil in comparison to group-A, where mortality rate was $20 \%$. Production of broilers in treated group was economic than control group. The treatment group recorded statistically non-significant increased live body weight than that of control group, and the hematological parameters (TEC, PCV, Hb and ESR) showed no difference as compared to control group. The profit margin (broiler $/ \mathrm{kg}$ ) of treated group was higher than control group. So, it can be concluded that NTG (Leaves of Neem and Tulsi, and gingers) extract as an effective and alternative of antibiotic growth promoters.

\section{Introduction}

Broilers meat as a cheap protein source is popular irrespective of religion. Due to lack of proper broiler rearing knowledge, farmers are using antibiotics as a growth promoter or life savings for chicken. As a result, each and every broiler is becoming a depot of antibiotics. When these broilers are consumed by human, this antibiotic residue enters into human body that may cause serious human health hazards with drug residues (Kibria et al., 2009). The risk of the presence of antibiotic residues in milk and meat and their harmful effects on human health has led to their prohibition for use in animal feed in the 
European Union. Prohibition of most of antimicrobial growth promoter, plant extracts have gained interest in animal feed strategies (Charis, 2000).

The neem tree Azadirachta indica from the family Meliaceae (Von Maydell, 1986) contains azadirachtin- a biologically active compound found in its seeds, bark and leaves which is responsible for its varied medicinal uses. Besides, it is known to induce some toxic effects; neem preparations fed to laying hens have been reported by Sadre et al., (1984) and Gowda et al., (1998) to significantly reduce the content of haemoglobin, erythrocyte count and packed cell volume. Ocimum sanctum (OS) is commonly known as Tulsi, reputed medicinal plant has recently been shown to possess very interesting pharmacological properties such as anti - inflammatory (Singh et al., 1993), Antioxidant (Uma Devi and Ganasoundari, 1999) and anti-stress properties (Sood et al., 2006). A decoction of Tulsi leaves is a popular remedy for cold (Pandey and Anita, 1990). In tulsi, biologically active compounds have been isolated from the leaves including ursolic acid, apigenin and luteolin that activates the cell mediated immune response and therefore, creates an enhanced response to any future challenges occurred by disease organisms. So, the feeding Tulsi leaves to immunosuppressed birds increase their humoral and cell mediate immune responses. Low dose of tulsi leaves extract have an inhibitory action on wide spectrum of microorganisms (Devakumar and Suktt, 1993). Recently, research on tulsi leaves as a growth promoter in broiler production has been started (Hasan et al., 2016) however it needs detail study to make feasible in field condition.

Zingiber officinale, commonly called gingeris a perennial plant. The efficacy of ginger is purported to be a result of its aromatic, carminative and absorbent properties (Govindarajan, $1982 \mathrm{a}, \mathrm{b}$ ). Besides, ginger is reported to have detoxification, anti-diabetic, and antiemitic potential (Egwurugwu et al., 2007; Al-amin et al., 2006). Extracts of different medicinal plant as a natural antimicrobials have been studied in recent years (Hsieh and Mau, 2001). Tulsi and neem extract in broiler production as a herbal growth promoter is found economic and safe (Khatun et al., 2013; Prasannabalaji et al., 2012). But there is no published report on effeicacy of three natural herbs (tulsi and neem leaves, and ginger ) in broiler production is found in literature. This is why, considering the present situation of poultry production, the work has been carried out with following objectives:

To evaluate the growth performance of broiler supplemented with neem and tulsi leaves, and ginger extract.

To investigate the effect of neem and tulsi leaves, and ginger on blood parameters of broiler.

\section{Materials and Methods}

This experiment was conducted to know the efficacy of NTG extract as a growth promoter in poultry. This experiment was carried out in the Department of Pharmacology, Faculty of Veterinary Science, Bangladesh Agricultural University, Mymensingh, Bangladesh. For this experiment, 1 day old broilers were collected from Kazi Farms Limited. The selected 20 chicks were allowed to acclimatize for 7 days in the experimental shed. The body weights (b.wt.) of assigned chickens were taken with digital weight machine and the results were recorded. During acclimatization the chicken were supplied with recommended feed and water. No antibiotic or vaccines were used in these experimental broilers. The randomly selected 
chicks were equally divided into 2 groups (Group A and Group B) for assessing the efficacy of herbal extract as a growth promoter on broilers, where group A $(n=10)$ served as control \& group B $(n=10)$ received the treatment of herbal extract. Broiler chicks were kept on a floor litter system in separate pens. A weight amount of the ration was offered to the birds twice a day and the left over feed was collected to calculate feed consumption of the birds.

Neem and tulsi leaves and ginger (NTG) were selected for effectiveness as growth promoter on broiler. Mature and disease free neem and tulsi leaves, and ginger were collected from BAU campus. For the preparation of dust, the leaves were sun-dried for 10 days and followed by oven at $55-60^{\circ} \mathrm{C}$ for 2 days. The dried leaves were pulverized with a blender. A 25 (unit) mesh diameter sieve was used to obtain the fine dust, after that dust was preserved in airtight plastic container until they were directly used for screening and preparation of water extract. A $10 \mathrm{~g}$ of each neem, tulsi leaves, and ginger powder was added to $270 \mathrm{ml}$ of distilled water and was shaking overnight at room temperature, filtered and distilled water was added up to $300 \mathrm{ml}$ to make $10 \%$ extract. To know the efficacy of herbal extract, group B were treated with $10 \%$ extract of neem and tulsi leaves, and ginger extract @ 1ml/ liter of drinking water for consecutive six weeks; and different experimental data were analyzed. The effect of the NTG extract on body weight, feed consumption and water consumption were recorded before and during administration of treatment. All birds were weighed in the morning, at noon and afternoon. The average of these three weights was calculated and recorded. Mean live weight gain of each group of fowls on $7^{\text {th }}$, $14^{\text {th }}, 21^{\text {st }}, 28^{\text {th }}, 35^{\text {th }}$, and $42^{\text {th }}$ days was recorded.
Blood samples were collected from wing vein of chicken of both control and treated groups at pre-feeding and during feeding at $21^{\text {st }}$ and $42^{\text {th }}$ days to study the effect of the NTG extract and different hematological parameter namely Total erythrocyte count (TEC), Hemoglobin estimation (Hb), Packed cell volume (PCV) and Erythrocyte sedimentation rate (ESR) were observed as described by Lamberg and Rothstein (1977). Routine post mortem examination of the treated birds was done to find out any abnormal changes. The experimental data were analyzed statistically between control and treated groups of chicken by student's t test. The differences were considered statistically significant at $5 \%$ level $(\mathrm{P}<0.05)$.

\section{Results and Discussion}

\section{Effect of NTG extracts supplementation on growth in broilers}

This experiment was conducted to know the efficacy of NTG extract as a growth promoter in broiler production. The birds using ration supplemented with $1 \mathrm{ml}$ of NTG extract gained the highest live wt among the treated groups compared with control. In Group A (Control group) live weight was measured and found that live wt on $7^{\text {th }}$ day $144 \pm 7.30$ $\mathrm{gm}$, final live wt $1600 \pm 58.02 \mathrm{gm}$, weight gain $1456 \pm 45.90 \mathrm{gm}$ and FCR 1.87; whereas, in Group B (NTG treated group) live wt on $7^{\text {th }}$ day was $145 \pm 7.30 \mathrm{gm}$, final live $\mathrm{wt}$ $1700 \pm 63.04 \mathrm{gm}$, weight gain $1555 \pm 36.90 \mathrm{gm}$ and FCR 1.82(Table-I). Dressing percentages between groups were compared but no significant $(\mathrm{P} \leq 0.05) \quad$ differences were observed (Table II); similarly, after slaughter, weight of different body organs such as heart, liver, spleen, gizzard and pancreas were compared and found no remarkable variation (Table II). In this experiment, 20\% mortality was observed in control group, whereas as no dead bird was found in treated group. 


\section{Economics of Production}

The average rearing cost of broiler kept under control and treatment groups viz A and B were Tk. 180.00 and Tk. 189.00, respectively (Table III). This figure does not include the cost of labour because the experiment was conducted in the Pharmacology research shed Bangladesh Agricultural University, Mymensingh.

Miscellaneous cost summed up Tk. 20 per broiler, which included the estimated cost of electricity, gas, litter and disinfectant. The average live weight of broilers in group A and B were $1.600 \mathrm{~kg}$ and $1.700 \mathrm{~kg}$ respectively. The broiler was sold in live weight basis at the rate of TK 130/kg. The net profit $/ \mathrm{kg}$ live weight in the respective group excluding the cost of labours was found Tk. 17.50 and Tk. 18.00 respectively. The level of NTG extract used in the ration exhibited their effect on the profit margin of the broiler.

\section{Study of NTG extract on hematological parameter of broilers}

Observation of hematological parameter (TEC, Hb, PCV, ESR) on $21^{\text {st }}$ day and $42^{\text {nd }}$ day did not show any significant difference $(\mathrm{P}<0.05)$ between the control (A) and NTG extract treated groups (B). The average live body weight (gm) of control (group-A) and treatment (group-B) after six weeks of the experimental period were $1600 \mathrm{gm}$ and 1700 gm, respectively.

It is observed from the results in Table I, that supplementation with NTG extract in group-B of broilers increase mean live weights, feed consumption and feed conversion efficiency as compared to control group (group-A); it might happen antimicrobial effect of NTG extract along with its digestion potential improved the food conversion ratio (Kale et al., 2003; Devakumar and Suktt, 1993).
Similarly, effect of tulsi leaf extract as a growth promoter on broiler production also studied by Hasan et al., 2016, and found significant increase of live weight. Tulsi with neem and other herbs as a growth promoter are found to have greater feed conversion efficiency in broilers (Nath et al., 2012; Khatun et al., 2013) which are in line with the present study. In a separate study, Siddig and Abdelati (2001) found higher weight gain in broilers in ration containing seeds of Nigella sativa and vitamin A.

Mollah et al., (2012) reported significant increase in the live weight of broilers treating feed with nishyinda, black pepper and cinnamon extract compared with control group. Similarly, Nagalakshmi et al., (1996) reported increase in feed conversion efficiency in nishyinda fed groups, which is in agreement with the findings of this study. In this experiment, untreated controlled group faced $20 \%$ mortality, and no birds were died in NTG treated group; it might happen that antimicrobial property of NTG extract protected bird from low doses of pathogen, whereas, controlled group failed to overcome the infection.

Supplementation of NTG extract was found to be more profitable than control group of broiler rearing. Increase in the profit margin of the birds fed rations containing herbal growth promoters may be attributed to the better efficiency of feed utilization, which resulted in more growth and better feed to gain ratio, ultimately leading to higher profit margin in the broilers.

Birds supplemented with NTG extract had higher body weight, weekly gain in weight, feed consumption and feed efficiency. These results may be due to antimicrobial (Devakumar and Suktt, 1993; Prasannabalaji et al., 2012) properties which help to reduce the microbial load of birds and improved the 
feed consumption and feed conversion efficiency of the birds. It is concluded that supplementation $1 \mathrm{ml}$ of NTG extract in drinking water treatment groups caused significant increase in live body weight and improvement in weight gain and feed conversion efficiency as compared to that of control group of poultry.

Table.1 Live weight gain, feed consumption and feed conversion ratio of broilers fed ( $1 \mathrm{ml} \mathrm{NTG} \mathrm{extract/L} \mathrm{from} 1$ to 6 weeks of age. Mean values within the same row indicated here no significant difference $(\mathrm{P}<0.05)$. In this and other tables, $\mathrm{A}=$ control, $\mathrm{B}=1 \mathrm{ml} / \mathrm{L}$ drinking water of NTG extract

\begin{tabular}{|c|c|c|}
\hline Variables & $\begin{array}{c}\text { Control } \\
\text { Gr. A }(n=10) \\
\text { mean } \pm \text { SD }\end{array}$ & $\begin{array}{c}\text { NTG treatment } \\
\text { Gr. B }(n=10) \\
\text { mean } \pm \text { SD }\end{array}$ \\
\hline $\begin{array}{l}\text { Initial live weight (gm) of day old } \\
\text { chicks }\end{array}$ & $46 \pm 1.80$ & $46 \pm 1.10$ \\
\hline Initial live weight (gm) on $7^{\text {th }}$ day & $144 \pm 7.30$ & $145 \pm 7.30$ \\
\hline Body weight (gm) on $14^{\text {th }}$ day & $482 \pm 2.30$ & $504 \pm 3.30$ \\
\hline Body weight(gm) on $21^{\text {st }}$ day & $810 \pm 7.90$ & $840 \pm 7.50$ \\
\hline Body weight (gm) on $28^{\text {th }}$ day & $1210 \pm 7.30$ & $1260 \pm 5.30$ \\
\hline Body weight (gm) on $35^{\text {th }}$ day & $1440 \pm 17.30$ & $1520 \pm 12.30$ \\
\hline Final live weight (gm) on $42^{\text {nd }}$ day & $1600 \pm 58.02$ & $1700 \pm 63.04$ \\
\hline Weight gain (gm) from on $7^{\text {th }}$ day & $1456 \pm 45.90$ & $1555 \pm 36.90$ \\
\hline Feed consumption $(\mathrm{gm})$ & 3000 & 3100 \\
\hline $\begin{array}{l}\text { Feed conversion ratio(feed } \\
\text { consumed/gm weight gain) }\end{array}$ & 1.87 & 1.82 \\
\hline
\end{tabular}

Table.2 Dressing percentages, relative giblet weight (heart, gizzard, liver and spleen) and pancreas weight of broilers fed administered @ $1 \mathrm{ml} / \mathrm{L}$ drinking water of NTG extract from 1-6 weeks of age. Mean values within the same row indicated here no significant difference $(\mathrm{P}<0.05)$

\begin{tabular}{|c|c|c|}
\hline Variables & $\begin{array}{c}\text { Control } \\
\text { Gr. A }(\mathbf{n = 1 0}) \\
\text { mean } \pm \text { SD }\end{array}$ & $\begin{array}{c}\text { NTG treatment } \\
\text { Gr. B }(\mathbf{n}=10) \\
\text { mean } \pm \text { SD }\end{array}$ \\
\hline Dressing percentage & $63.59 \pm 1.02$ & $63.09 \pm 1.14$ \\
\hline Relative heart weight & $0.45 \pm 0.21$ & $0.46 \pm 0.20$ \\
\hline Relative gizzard weight & $1.48 \pm 0.33$ & $1.52 \pm 0.28$ \\
\hline Relative liver weight & $2.60 \pm 0.15$ & $2.61 \pm 0.20$ \\
\hline Relative spleen weight & $0.12 \pm 0.024$ & $0.12 \pm 0.040$ \\
\hline Relative pancreas weight & $0.28 \pm 0.028$ & $0.29 \pm 0.029$ \\
\hline
\end{tabular}


Table.3 Cost-benefit analysis of broiler production by using feed supplemented with NTG extract from 1 to 6 weeks of age. Mean values within the same row indicated here no significant difference $(\mathrm{P}<0.05)$. In this and other tables,

$\mathrm{A}=$ control, $\mathrm{B}=1 \mathrm{ml} / \mathrm{L}$ drinking water of NTG extract

\begin{tabular}{|c|c|c|}
\hline Variables & $\begin{array}{c}\text { Control } \\
\text { Gr. A (n=10) } \\
\text { mean } \pm \text { SD }\end{array}$ & $\begin{array}{c}\text { NTG treatment } \\
\text { Gr. B (n=10) } \\
\text { mean } \pm \text { SD }\end{array}$ \\
\hline Cost/chick (Tk.) & 40 & 40 \\
\hline Average feed consumed (kg)/chicks & 3.000 & 3.100 \\
\hline Feed price/Kg (Tk.) & 40 & 40 \\
\hline Cost of herbal growth promoters (Tk.) & 0.00 & 5 \\
\hline Feed cost (Tk.) & 120.00 & 124.00 \\
\hline Miscellaneous (Tk.) & 20 & 20 \\
\hline Total cost/broiler (Tk.) & 180.00 & 189.00 \\
\hline Average live weight (gm) & $1600 \pm 58.02$ & $1700 \pm 63.04$ \\
\hline Sale price/Kg live wt. (Tk.) & 130 & 130 \\
\hline Sale price/broiler (Tk.) & 208.00 & 221.00 \\
\hline Net profit/broiler (Tk.) & 28.00 & 32.00 \\
\hline Profit/Kg live weight (Tk.) & 17.50 & 18.82 \\
\hline
\end{tabular}

The studied herbs namely, neem, tulsi and ginger in optimum doses have almost no side effect on human food consumption. Bitter test of some herbal promoter may have significant influence in hematological parameter such as PCV, ESR and Hb (Nagalakshmi et al., 1996; Gowda et al., 1998) but in this mixed herbal extract, NTG no such adverse effect was observed (Table IV). The study period only 16 weeks this is much less than the normal life span of RBC.

In this study, NTG extract acts as an alternative growth promoter. This result may be due to antibacterial, anti-inflammatory, anti-stress, antifungal, insecticidal and liver tonic properties of NTG extract which ensures lower microbial load in birds and improve the feed consumption and feed efficiency. Care should be taken to ensure its safe use for medicinal references. In this experiment, effect of NTG extract was studied in terms of growth promoter on broilers. The experiment was conducted in the Department of Pharmacology, Faculty of Veterinary Science, BAU, Mymensingh. A total of 20 days old commercial broilers was equally divided into two groups $(n=10)$ to carry out this research work. Keeping one group as control group (A) and another one (B) as a group subjected to treatment with NTG extract. Group B was supplemented with NTG extract @ 1 ml/litre in drinking water, and group A was provided with the fresh water. Weekly observations were recorded in live body weight for $6^{\text {th }}$ weeks and blood parameters of birds at $21^{\text {st }}$ and $42^{\text {th }}$ days. The treatment group $B$ recorded no significant $(\mathrm{P}<0.05)$ for live body weight than that of control group $\mathrm{A}$, and no significant $\quad(\mathrm{P}<0.05) \quad$ differences were observed in hematological parameters between experimental groups. 
Table.4 Hematological parameters. Comparison of total RBC, Hb, PCV and ESR of Broilers fed @ $1 \mathrm{ml}$ NTG extract /L from 1 to 6 weeks of age. Mean values within the same row indicated here no significant difference $(\mathrm{P}<0.05)$

\begin{tabular}{|c|c|c|c|}
\hline $\begin{array}{l}\text { Experimental } \\
\text { period }\end{array}$ & \multicolumn{2}{|c|}{$\begin{array}{c}\text { Treatment } \\
\text { (Neem, Tulsi leaves and Ginger) }\end{array}$} & Mean \pm SEM \\
\hline \multirow[t]{8}{*}{$21^{\text {st }}$ day } & \multirow{2}{*}{$\begin{array}{c}\mathrm{RBC} \\
\left(\text { million } / \mathrm{mm}^{3}\right)\end{array}$} & Neem, Tulsi leaves and Ginger & $197.39 \pm 5.54$ \\
\hline & & Control & $191.38 \pm 4.37$ \\
\hline & \multirow{2}{*}{$\begin{array}{l}\mathrm{Hb} \\
(\mathrm{gm} \%)\end{array}$} & Neem, Tulsi leaves and Ginger & $6.46 \pm 0.07$ \\
\hline & & Control & $6.10 \pm 0.14$ \\
\hline & \multirow{2}{*}{$\begin{array}{l}\mathrm{PCV} \\
(\%)\end{array}$} & Neem, Tulsi leaves and Ginger & $19.10 \pm 0.60$ \\
\hline & & Control & $16.33 \pm 0.88$ \\
\hline & \multirow{2}{*}{$\begin{array}{c}\text { ESR } \\
\left(\mathrm{mm} \text { in } 1^{\mathrm{st}}\right. \\
\text { hour })\end{array}$} & Neem, Tulsi leaves and Ginger & $8.66 \pm 0.88$ \\
\hline & & Control & $10.67 \pm 0.86$ \\
\hline \multirow[t]{8}{*}{$42^{\text {nd }}$ day } & \multirow{2}{*}{$\begin{array}{c}\mathrm{RBC} \\
\left(\mathrm{million} / \mathrm{mm}^{3}\right)\end{array}$} & Neem, Tulsi leaves and Ginger & $297.67 \pm 12.12$ \\
\hline & & Control & $248.70 \pm 13.87$ \\
\hline & \multirow{2}{*}{$\begin{array}{c}\mathrm{Hb} \\
(\mathrm{gm} \%)\end{array}$} & Neem, Tulsi leaves and Ginger & $7.64 \pm 0.2$ \\
\hline & & Control & $6.92 \pm 0.27$ \\
\hline & \multirow{2}{*}{$\begin{array}{l}\mathrm{PCV} \\
(\%)\end{array}$} & Neem, Tulsi leaves and Ginger & $20.71 \pm 0.34$ \\
\hline & & Control & $17 \pm 0.61$ \\
\hline & \multirow{2}{*}{$\begin{array}{c}\text { ESR } \\
\left(\mathrm{mm} \mathrm{in} 1^{\text {st }}\right. \\
\text { hour })\end{array}$} & Neem, Tulsi leaves and Ginger & $4.00 \pm 1.01$ \\
\hline & & Control & $7.00 \pm 0.60$ \\
\hline
\end{tabular}

Net live weight gain was increased in NTG extract treated group $(1700 \pm 63.04 \mathrm{gm})$ than control group $(1600 \pm 58.02 \mathrm{gm})$ and profit/ $\mathrm{kg}$ live broiler was Tk. 18.82 in treatment group and in control group was Tk. 17.50. From this experiment, it is observed that production cost can be reduced by eliminating vaccines and antibacterial. This technique is easy to implement at field level as an alternative of antimicrobial growth promoter.

This is a very short-term (only 42 days) experiment to evaluate the medicinal value of NTG extract. Before field application of NTG extract as growth promoter and as an alternative for antibiotic growth promoter further trial on a large scale basis is needed and also to make the findings more accurate and effective further study is essential to determine the different antibody levels in broilers of treated group by exposing some organisms in experimental broilers before culling of experimental birds.

\section{References}

Al-amin, Z. M., Thomson, M., Al-qattan, K. K., Peltonen-Shalaby, R. and Ali, M. 2006. Anti-diabetics and hypolipideamic properties of ginger (Zingiber officinale) in streptozotocininduced diabetic rats. Br. Journ. Nutr. 
96:660-666.

Charis, K. 2000. A novel look at a classical approach of plant extracts. Feed Mix (special issue on Nutraceuticals) 19-21.

Devakumar, C. and Suktt, D. 1993. Chemistry. In: Randhawa, N.S. \& Parmar, B.S. (eds), Neem Research and Development. Soc. of Pesticide Sci., New Delhi, pp (India, society of pesticide science).

Egwurugwu, J. N., Ufearo, C. S., Abanobi, O. C., Nwokocha, C. R., Duruibe, J. O., Adeleye, G. S., Ebunlomo, A. O. and Onwufuji, O. 2007. Effects of ginger (Zingiber officinale) on cadmium toxicity Afr. J. Biotech Vol. 6 (18): 2078-2082.

Govindarajan, V. S. 1982a. Gingerchemistry, technology, and quality evaluation: part 1. Citr Rev Food Sci Nutr 17, 1-96.

Govindarajan, V. S. 1982b. Gingerchemistry, technology, and quality evaluation: part 2. Citr Rev Food Sci Nutr 17, 189-258.

Gowda, S. K., Verma, S. V., Elangovan, A. V. and Singh, S. D. 1998. Neem (Azadirachta indica) kernel meal in the diet of White Leghorn layers. Br Poult Sci. Dec;39(5):648-52.

Hasan, M. N., Mostafa, M., Sorwar, M. G., Hasan, M. T., Das, K. and Hossain D. M. N. 2016. Effects of tulsi leaf extract on body weight gain in broiler production. Bangl. J. Vet. Med. 14 (1): 21-25.

Hsieh, P. C. and Mau, J. L. 2001. Antimicrobial effect of various combinations of plant extracts. Food Microbiology. 18: 35-43.

Kale, B. P., Kothekar, M. A., Tayade, H. P., Jaju, J. B. and Mateenuddin, M. 2003. Effect of aqueous extract of Azadirachta indica leaves on hepatotoxicity induced by antitubercular drugs in rats. Indian Journal of
Pharmacology. 35: 177-180.

Khatun, S., Mostofa, M., Alom, F., Uddin, J., Alam, M. N. and Moitry, N. F. 2013. Efficacy of tulsi and neem leaves extract in broiler production. Bangl. J. Vet. Med. 11 (1): 1- 5.

Kibria, A. S. M. G., Awal, M. A., Mostofa, M., Saifuddin, A. K. M., Alam, M. R. and Asgar, M. A. 2009. Detection of tetracycline residues in broilers of Chittagong. J. Environ. Sci. and Natural Resources. 2(2): 41-44.

Lamberg, S. L. and Rothstein, R. 1977. Laboratory manual of hematology and urinalysis. Avi. Publishing Company, Inc, West Port Connecticut, U.S.S.R.

Mollah, M. R., Rahman, M. M., Akter, F. and Mostofa, M. 2012. Effects of nishyinda, black pepper and cinamon extract as growth promoter in broiler. The Bangladesh Veterinarian. 29 (2): 69-77.

Nagalakshmi, D., Sastry, V. R. B., Agrawal, D. K., Katiyar, R. C. and Verma, S. V. S. 1996. Performance of broiler chicks fed on alkali treated neem (Azadirachta indica) kernel cake as a protein supplement. British Poultry Science 37(4): 809-818.

Nath, D. D., Rahman, M. M., Akter, F. and Mostofa, M. 2012. Effects of Tulsi, Black pepper and Cloves extract as a growth promoterr in broiler. Bangladesh Journal of Veterinary Medicine. 10 (1\& 2): 33-39.

Pandey, B. P. and Anita. 1990. In: Economic Botany (Published by Chand and Company Ltd., Ramnagar, New Delhi). p. 294

Prasannabalaji, N., Muralitharan, G., Sivanandan, R. N., Kumaran, S. and Pugazhvendan, S. R. 2012. Antibacterial activities of some Indian traditional plant extracts. Asian Pacific Journal of Tropical Disease. 2: S291S295.

Sadre, N. L., Deshpande, V. Y., Mendulkar, 
K. N. and Nandal, D. H. 1984. Male anti-fertility activity of azadirachta indicaa. Juss (Neem) in different species. p. $473-482$.

Siddig, R. M. and Abdelati, K. 2001. Effect of dietary vitamin A and $N$. sativa on broiler chick's performance. In proceeding: 10th International Conference of Association for Tropical Veterinary Medicine and Livestock.Community and Environment, Copenhagen, Denmark.

Singh, L. K., Pang, X., Alexacos, N., Netaumen, R., Theoharides, C. 1993. Acute immobilization stress triggers skin mast cell degranulation via corticotropin releasing hormone neurotension and substance link to neurogenic skin disorders. Brain, Behavior, and Immunity, 13: 225- 239.
Sood, S., Narang, D., Thomas, M. K., Gupta, Y. K. and Maulik, S. K. 2006. Effect of Ocimum sanctum Linn on cardiac changes in rats subjected to chronic restraint stress. Journal of Ethnopharmacology. 108: 423-427.

Uma Devi, P. and Ganasoundari, A. 1999. Modulation of glutathione and antioxidant enzymes by Ocimum sanctum and its role in protection against radiation injury. Indian Journal of Experimental Biology, 37: 262-268. ISSN: 0019- 5189.

Von, Maydell, H. J. 1986. Trees and Shrubs of the Sahel, their characteristics and uses. Deutsche Gesellschsft fur Technisque Zusammenarbeit- GTZ Technical Repot No. 399. Federal Republic of Germany. p. 173-175.

\section{How to cite this article:}

Biswas. S. S., M. Mostafa and Saha. S. S. 2020. Effects of Neem, Tulsi and Ginger Extract as a Growth Promoter in Broilers Production. Int.J.Curr.Microbiol.App.Sci. 9(03): 1331-1339. doi: https://doi.org/10.20546/ijcmas.2020.903.155 